\title{
Financial Management, Savings Behavior, Investment Behavior and Financial Well-Being of Working Women in the Public Sector
}

\author{
Mohamad Fazli Sabri ${ }^{\text {a,1,* }}$, T.Syahrul Reza ${ }^{\text {b,2 }}$, Rusitha Wijekoon ${ }^{c, 3}$ \\ 1,3 Faculty of Human Ecology, Universiti Putra Malaysia, 43400 UPM Serdang, Selangor, Malaysia. \\ 2 Institut Ilmu Sosial dan Manajemen STIAMI, Jakarta, Indonesia \\ ${ }^{1}$ fazli@upm.edu.my*; ${ }^{2}$ ts.reza@ stiami.ac.id, ${ }^{3}$ wrusitha@yahoo.com * \\ corresponding author
}

\section{ARTICLE INFO}

Article history

Received 2020-08-29

Revised 2020-09-12

Accepted 2020-09-19

Keywords

financial well-being, malaysia, investment behavior, working women

\begin{abstract}
Women have made an amazing progress personally, financially, and professionally however, with regards to the field of finance, an extensive effort to be done to become well performers comparing to the men. Therefore, women must begin understanding, and thinking the significance of money, savings, and its investment perspectives to overcome critical circumstances at any phase of their lives. Therefore, the major objective of this research is to determine the financial management, savings behavior, investment behavior, and financial well-being $(F W B)$ of working women in the public sector in Malaysia. A sum of 722 respondents were selected using the multi-stage random sampling method in Malaysia. According to the financial status of working women, 39. $2 \%$ felt that their assets were more than their debt, and $44.3 \%$ was said that their salary was sufficient to meet only their basic requirements. Furthermore, more than $80 \%$ of the respondents were followed good financial management practices such as, keeping updated records of the expenses, planning the expenses, doing investments monthly, keeping the loan payment on schedule, settling all the bills on time, and maintaining a savings account. Moreover, it also showed that Malaysian working women have good financial management practices which are indicated by their abilities in performing the savings and investment behaviors to manage their surplus money wisely in order to achieve higher FWB levels. Further, this study was detected some specific financial challenges that Malaysian public sector working women meet over their lifetime, and offered possible solutions for the present and future.
\end{abstract}

\section{INTRODUCTION}

Nowadays, the individuals and households in Malaysia are more conscious of their financial management practices due to the expanding cost of living. Financial difficulties have had an effect on how Malaysians spend, invest, save, and oversee challenges so as to secure their standard of living, particularly for the long term. Current higher levels of consumer indebtedness, and expanding focus on personal concern for financial planning indicate that there is a developing requirement for better financial management understanding among Malaysians. Today's consumers are also confronted with the unpredictability of financial products in the marketplace, thus increasing the need for them to manage their finances.

There are many reasons for financial difficulties. Poor financial management and behaviors are regularly go together with individual financial issues. One reason for individual financial issues is financial illiteracy experienced by individuals and families. Apart from that, the combination of financial issues, for example, low income, high debt, and lower degrees of financial literacy might unfavorably influence the FWB of individuals and households. Due to the influence of the elevated

cost of living, vast majority have today alerted more regarding their financial prosperity and are savvier in spending therefore, they can experience a comfortable life, and better plan for their financial future. 
Women represents more than $50 \%$ of the total world population, and their involvement is about 55\% together with their unpaid financial exercises. Thus, women should do an equivalent role in financial decision making. Today, graduation of women is higher than men from colleges and graduate schools, representing $57 \%$ of latest degree earners. Due to some degree to this ascent in education, there has been a sudden increment in working women, and women's earnings. Furthermore, financial education assumes a major job to enhance financial behavior, which thus prompts to healthier FWB. With the expansion in role of women in the economic exercises and naturally, women are being distinguished as a superior saver than men, the decision making process by women for investment purpose gains its significance. Even though, the savings have positive correlation with FWB, the degree of savings among Malaysian working adults leave much to be desired. Very nearly two out of each ten individuals (18\%) can't make any investment funds over the most recent a half year. Somewhat more than half of the participants (53\%) are just ready to save between $1 \%$ to $10 \%$ of their income; $16 \%$ can just save between $11 \%$ to $20 \%$ of their salary, and a mere $13 \%$ saved more than $20 \%$ of their income. All things considered, females save a higher percentage $(10.18 \%)$ of their salary contrasted with males $(8.85 \%)$. In light of the profile, this survey additionally revealed that female Malaysian adults are in enhanced financial state with an average score of 6.35 while the males scored 6.05.

Usually, women have been increasingly reluctant with regards to financial investments. They are highly watchful with regards to money. Nonetheless, the current women, who are similarly engaged in jobs, have familiar about numerous aspects of investments via their educational qualifications, and accordingly they invest in several investment avenues for example, debentures, shares, commodities, mutual funds, and bank deposits. The working women have a more prominent tendency to save and invest as a result of their independent earning ability. With expanding level of information and mindfulness, women are gradually contributing in the risk investment portfolios and they are getting expository in their investment behavior. Furthermore, AKPK Financial Behavior Survey (2018) have shown that a positive association between the degrees of financial knowledge and FWB, further affirming the significance of securing financial knowledge.

Working women in Malaysia presently take an interest in all exercises, for example, media, education, politics, science and technology, and so on. With an evolving scenario, they have begun effectively taking an interest in investing their excess money, however everything relies on the different parameters, for example, level of their hazard taking capacity, impact of relatives and companions and the challenge to get exposed to innovative and modern investment ventures. Furthermore, women represent approximately 50 percent of most countries population, and thus 50 percent of the potential workforce. Mboko and Smith-Hunter (2009) argued that this workforce is often marginalized, and exist on peripheral boundaries of a country's mainstream labour market facing obstacles, and being denied their rightful place as contributing income earners in their society

Therefore, the major objective of this research is to explain descriptively the status of the variables; financial management, savings behaviour, investment behavior, and FWB of working women in the government departments in Malaysia.

\section{Financial Management}

"Financial management is planning, organizing, directing and controlling the financial activities by applying general management principles to the financial resources". Healthy financial management ought to incorporate different financial practices, for example, credit management, cash management, estate planning, and retirement planning. It is performed in each household to make the best utilization of the accessible money. Despite the fact that, there is a huge contrast in earnings between women and men, a study revealed that women take on a considerable quantity of responsibility for their families' financial management, including emergency payments, remittances, and daily household management.

Nyamwanza, Mapetere, Mavhiki, and Dzingirai (2012) identified difficulties confronted by women entrepreneurs in managing business finances and the importance of the financial management skills to enhance their business growth. In the study of Okapara (2009) noted that lack of management skills, for example, inventory management, bookkeeping, personnel management, and basic marketing of women, and hence, most entrepreneurs end up losing track of their day by day transactions, and cannot represent for their expenses and profits at the end of the month. It is also compatible with the outcomes of the 
research which was led by Karami, Moradi, Mazhari, Yarkarami, and Khan (2014) with women entrepreneurs in Malaysia.

Another study also emphasized on the need for providing financial management skills, that helps in development and or improve the entrepreneurial abilities amongst women entrepreneurs which in turn would enable them in enhancing their future business prospects and growth. Furthermore, Mboko and Smith-Hunter concluded that a key way to deal with small firms is essential for the development and suggested that Malaysian female entrepreneurs be supported through the arrangement of managerial training that highlight the necessity to manage and execute the chosen system.

\section{Savings Behavior}

Women have been shown to save differently than men, but little is known about whether or how general saving behaviors differ between men and women. Lusardi and Mitchell (2007) found that women were generally less financially knowledgeable as compared with men, and financial literacy was found to affect both savings and portfolio choice. In their examination of the extent to which saving behavior differed among households in different marriage states, Lupton and Smith (2003) found that much of saving behavior was left unexplained even after controlling for demographic and socioeconomic characteristics of the household. Another study showed that the saving behaviors of men and women were differ. Further, the descriptive analysis of the men and women in the sample showed that women were less likely than men to have saved over the previous year, while the proportion of the male and female samples reporting to save regularly was similar.

Financial innovation has expanded investment and savings opportunities in Malaysia, and they ought to likewise have the option to recognize appropriate financial products dependent on their objectives, and risk appetites, and have to do informed financial decisions. Sabri and Juen (2014) observed that saving behavior is one of the major important factors that increase the retirement confidence of the working women in Malaysia. On the other side some experts have opposite results of their studies that the genders have no effect on saving behavior. For example, gender difference has no impact in the dollar holdings of stocks.

\section{Investment Behavior}

Investment implies organization of time, energy, or different assets to procure profitable returns in the form of income, interest, or appreciation of the instruments. From the view point of economics, investment is the accumulation of newly produced entities, for example, inventories, buildings, equipment, etc. But, the finance professionals define investment as acquisition of asset with the desire of profits and/or capital appreciations. An investor is an individual who disperses the capital with the desire of financial gain, and investment behavior relies upon the mentality of the investors. Each investor desires his/her hard earned savings to be invested in a highly secured, lucrative, and liquid sector, because savings and investments are correlated. According to Delafrooz and Paim (2011), financial literacy was found to assume a significant job in clarifying attitudes toward saving and investments. However, the investment pattern of the working women is distinctive due to regular flow of income, tax saving benefits, security, safety, retirement benefits as opposed to professionals and businessman.

Given the complexity of current financial instruments and the financial decisions required in everyday life, for example, deciding how much to save, contrasting distinctive financial instruments to invest, when and where to get the financing, when and where to invest, people need to realize how to peruse and compose their financials. Past examinations have additionally recorded that sex and age have a few ramifications on investment choices. For example, Schmidt and Sevak (2006) depict how family wealth in the United States differs by sex and household type and found that women's investments, generally had been lower than of men's because of social and numerous demographic concerns.

Based on a study on Indonesian female academicians the researchers observed that those characteristics of the respondents' will impact on their investment choice, because it is accompanying with the tolerance of risks, and they observed three behaviors related to the investments. First they thought about investment plan can get cost-effective investment if they do financial planning and investment/saving. Secondly, most of the participants were progressively keen on property investments. 
The final type of behavior persuading women workers in doing investment is themselves, similar to household security reason, and retirement planning. Watson and McNaughton (2007) found that women tend to take lower risks for their investment. Bernasek and Shwiff (2001) found that the married women prefer pension plan as their investment sector. Sellappan et al. (2013) found that married women are more curious in making investment than the unmarried Jain (2014) revealed that women prefer gold as good investment, and fixed deposit in bank as the safe investment options for tax saving purpose.

\section{FWB}

Well-being is a multi-dimensional concept. Van-Praag, Frijters, and Ferrer-i-Carbonel (2003) defined well-being as "the individual satisfaction in the related six areas: Finance; Leisure; Environmental; Business; Home and Health". FWB is firmly linked with personal traits, attitudes of the individual, and financial knowledge. The Consumer Financial Protection Bureau (CFPB; 2015) narrowly defines FWB as "a state of being wherein a person can fully meet current and ongoing financial obligations, can feel secure in their financial future, and is able to make choices that allow enjoyment of life". Joo (2008) derived a definition of FWB from the general well-being and narrowly defines it as "a state of been financially healthy, happy and free from worry".

FWB is a theoretical concept which is used to describe the financial situation of an individual or family. Previously, FWB is perceived as happiness or satisfaction towards financial situation. The World Bank (2013) observes that, policy makers over the world are worried about how the family FWB could be improved to uplift the financial sector and increase its steadiness. Sabri and Falahati (2003) studied FWB among Malaysian employees, and financial behavior, financial literacy, financial problem, financial capability, and financial stress were identified as the major determinants of the FWB. Further, they revealed that the factor financial stress had a partial mediation effect on predicting FWB. Furthermore, Mokhtar, Husniyah, Sabri1 \& Talib (2015) have profiled the FWB, and socio-economic level among public employees in Malaysia.

According to Close Brothers' FWB Index, there is also a FWB gap between men and women. The Index measures employees' financial health, showing how financially fit they feel across eight categories; budgeting and planning, debt, money worries, protection, retirement, properties and mortgages, savings and investments, and tax. Each category is scored out of 100, and there is also an overall index score, based on the average of the category scores. It revealed that the women lag behind men in terms of their overall FWB, with an overall score of 48.1, compared to 58.3 for men Further, it is evident that financial literacy of women has a noteworthy influence on the household FWB. In the investigation of Haque and Zulfiqar (2016) revealed that the existence of FWB, financial literacy, and positive financial attitude is essential for the economic empowerment of working women. Furthermore, most of the women live longer, earn less and do not plan as efficiently for their FWB as do men.

\section{METHOD}

\section{Sampling}

A total of 1,000 respondents were selected using a multi-stage random sampling method. As a first stage, five states in Malaysia were selected randomly, and they were Penang, Johor, Terengganu and Perak from Peninsular Malaysia, and Sarawak from East Malaysia. From each state, a total of 200 respondents were targeted to get the sample of 1000. At the next stage, the government websites were utilized to identify government agencies in a random manner, and five departments were selected. Then 40 respondents were selected from each department to become the sample size 200, and questionnaires were distributed to each state with the total of 1,000 questionnaires. However, only a total of 722 duly filled questionnaires were returned with the response rate of $72.2 \%$.

\section{Instrument}

Self-administered questionnaire was used as the study instrument. There were five sections in this instrument, which includes the following:

Respondent's Profile

Mohamad Fazli Sabri (Financial Management, Savings Behavior, Investment Behavior and Financial Well-Being... ) 
The demographic characteristics such as, age, marital status, ethnicity, educational background, monthly household income and financial status were asked from the respondents.

\section{Financial Management}

Financial management was measured by an instrument adopted from Danes and Hira (1987); Gutter and Copur (2011); Hogarth and Anguecov (2004). This section was used to measure how respondents manage their finances and contained 33 items with "Yes" and "No" answers. The respondents were asked to choose the most suitable statement, which fit them well. All the points which were taken for the each and every item were summed up to calculate the total score, where the total score was ranged from 0 to 33 .

\section{Savings}

Savings were adopted from Haron, Sharpe, Abdel-Ghany, and Masud (2012), and was used to determine the respondents' saving habits. There were eight items under this section. Respondents were given several options to choose which fits them the most.

\section{Investment}

The major purpose of this section was to determine how respondents made their investment decisions. There were 11 items to choose which fit the respondents the most.

$F W B$

Measurement of the FWB was taken from the Malaysian Personal FWB Scale (MPFWBS) developed by Garman and Jariah (2006) based on the adaption of the Incharge Financial Distress/ FWB (IFDFW) by O'Neill, Prawitz, Sorhaindo, Kim, and Garman (2006). This section was consisted 12 items with answer option based on a scale from very unsatisfied (1) to very satisfied (10).

\section{RESULTS AND DISCUSSION}

\section{Profile of the Respondents}

Background characteristics of the participants are presented in the Table 1. More than onethird $(36.4 \%)$ of the participants were aged between 30 to 39 years. The mean age of the participants was 35.83 years. Most of the participants were Malay $(88.3 \%)$, followed by Chinese (2.3\%), Indian (2.3\%), and other ethnic groups (6.6\%). Around $72.2 \%$ of the respondents were married, and $24.7 \%$ respondents were still single. When considering the educational background of the participants, $99.2 \%$ had completed their secondary education and above. Moreover, the monthly income of the majority of the respondents (74.6\%) ranged from RM1000 to RM3000 (USD 933). The average income was RM1,247.85.

Table 1. Respondents' Background Characteristics ( $N=722)$

\begin{tabular}{lcc}
\hline Items & Frequency & (\%) \\
\hline Age (years) & 229 & 31.6 \\
$20-29$ & 264 & 36.4 \\
$30-39$ & 121 & 16.7 \\
$40-49$ & 108 & 14.9 \\
50 and above & & \\
Mean= 35.83 & & \\
Ethnic & 640 & 88.3 \\
Malay & 17 & 2.3 \\
Chinese & 17 & 2.3 \\
Indian & 48 & 6.6 \\
Others & & 72.2 \\
Marital Status & 521 & 24.7 \\
Married & 178 & 3.2 \\
Single & 23 & \\
Widowed/Divorced & &
\end{tabular}




$\begin{array}{lrr}\text { Primary School } & 6 & 0.8 \\ \text { Secondary School } & 347 & 48.1 \\ \text { Diploma } & 248 & 34.3 \\ \text { Bachelor } & 114 & 15.8 \\ \text { Master/ PhD } & 7 & 1.0 \\ \text { Monthly Income (RM) } & & \\ \text { Below 1,000 } & 32 & 4.1 \\ 1,000-3,000 & 560 & 74.6 \\ 3,001-5,000 & 82 & 10.7 \\ 5,001 \text { and above } & 7 & 0.8\end{array}$

Mean $=1,247.85$

Table 2 describes the financial status of the respondents. The greater part of the participants $(57.5 \%)$ mentioned that their monthly saving percentage was around 1\% to 10\%. Nearly $39.2 \%$ participants confirmed that their debt were lesser than their assets, trailed by $33.7 \%$ felt that their debt and assets were equal, and $23.9 \%$ were aware that their debt were higher than their assets. Besides that, participants' current income adequacy was asked. Around 44.3\% participants mentioned that their income is enough to fulfill their basic needs, and $29 \%$ of the respondents indicated that their income was sufficient to cover most of the expenses. Whereas, $16.1 \%$ respondents showed that their income was sufficient to buy all the things they wished for and also had money to save. About $42.9 \%$ respondents reported that their retirement fund was not enough. Results also showed that majority of the respondents $(81.8 \%)$ considered their pensions as their retirement income source in the future, and $56.4 \%$ kept savings as their source of income during the retirement life. However, only $5.9 \%$ respondents prepared a retirement account in a bank as their income source for the retirement life.

Table 2. Financial Status of the Respondents $(N=722)$

\begin{tabular}{lrr}
\hline Items & Frequency & $\mathbf{( \% )}$ \\
\hline Monthly Saving & 47 & 6.5 \\
$0 \%$ & 417 & 57.5 \\
$1 \%-<10 \%$ & 193 & 26.6 \\
$10 \%-<20 \%$ & 50 & 6.9 \\
$>20 \%$ & & \\
Asset to Debt Ratio & 173 & 23.9 \\
Assets less than debt & 244 & 33.7 \\
Assets equal to debt & 284 & 39.2 \\
Asset more than debt & & 9.1 \\
Income Adequacy & 66 & 44.3 \\
Not enough & 321 & 29.0 \\
Enough for basic needs & 210 & 16.1 \\
Enough for most things & 117 & 42.9 \\
Enough and can save money & & 53.8 \\
Retirement fund & 311 & 1.9 \\
Not enough & 390 & 81.8 \\
Enough & 14 & 5.9 \\
More than enough & & 20.4 \\
Sources of Retirement Income & 593 & 15.6 \\
Pension & 43 & 24.8 \\
Retirement account in bank & 148 & 56.4 \\
Employment Provident Fund & 113 & 11.5 \\
Life Insurance & 180 & 2.4 \\
Investment & 407 & 83 \\
Savings & 17 & \\
Children & & \\
Others & & \\
\hline
\end{tabular}




\section{Financial Management}

Based on the Table 3,86.1\% respondents always kept their records of the expenses updated. About 95.4\% always planned their expenses or budget, and $83.6 \%$ did their investments monthly. Around 76.2\% respondents indicated that they were not leased their good for cash. Meanwhile, $79.2 \%$ respondents kept their loan payment on schedule, and $94.7 \%$ cleared all their bills on time. But, $61.4 \%$ respondents do not use the credit facilities even for daily use. Only $39.3 \%$ respondents borrowed money from their family, partner, friends or supervisor, and $90.5 \%$ respondents always tried to settle their loan earlier. Therefore, maintaining of these good habits should keep their FWB levels higher. Further, 78.4\% respondents pay their debt through payroll deduction, but $93.3 \%$ respondents do not borrow money from illegal loan sharks, and showed that they had the common sense on not to borrow money through illegal means. Only $66.1 \%$ respondents constantly kept their money in savings accounts, and $80.9 \%$ respondents started to save for their old age, and it is advisable to practice this habit when a person starts working in order to achieve a higher level of retirement confidence during the old age [48]. Besides that, $57.9 \%$ individuals did not save for their children's education. Other than that, $85.4 \%$ did prepare an amount of saving for emergencies, and showed that the importance of saving for any unpredictable circumstances. Moreover, $85.7 \%$ respondents also did savings as a long term goal. About $84 \%$ of the respondents planned carefully before taking any loan, and $77 \%$ had a financial planning needs to meet short term goals. Only 55.3\% respondents owned a fixed deposit account, and $89.5 \%$ respondents owned a saving account.

Table 3. Financial Management Data

\begin{tabular}{|c|c|c|c|c|c|}
\hline & Activities & Yes & $(\%)$ & No & $(\%)$ \\
\hline 1. & Keep an expenses record & 617 & $(86.1)$ & 100 & 13.9 \\
\hline 2. & Plan for expenses or budget & 691 & $(95.4)$ & 26 & 3.6) \\
\hline 3. & Investment monthly & 597 & $(83.6)$ & 117 & 16.4) \\
\hline 4. & Lease of goods for cash & 171 & $(23.8)$ & 546 & $(76.2)$ \\
\hline 5. & Loan payment/ credit made on schedule & 566 & $(79.2)$ & 149 & $(20.8)$ \\
\hline 6. & Pay all the bill in time (utility bill) & 677 & $(94.7)$ & 38 & $(5.3)$ \\
\hline 7. & Using credit facilities even for daily use & 275 & $(38.6)$ & 438 & $(61.4)$ \\
\hline 8. & Borrow money from family, spouse, friends or supervisor & 281 & $(39.3)$ & 434 & $(60.7)$ \\
\hline 9. & Try to settle the loan/ debts earlier & 647 & $(90.5)$ & 68 & $(9.5)$ \\
\hline 10. & Debt payments are made through payroll deduction & 561 & $(78.4)$ & 155 & $(21.6)$ \\
\hline 11. & Borrow money from loan sharks or illegal loan sharks & 48 & $(6.7)$ & 668 & $(93.3)$ \\
\hline 12. & Cut spending to meet budget constraints & 643 & $(90.1)$ & 71 & $(9.9)$ \\
\hline 13. & Minimize tax payment & 449 & $(63.0)$ & 264 & $(37.0)$ \\
\hline 14. & Pay zakat & 603 & $(84.2)$ & 113 & $(15.8)$ \\
\hline 15 . & Have financial goal & 662 & $(92.7)$ & 52 & $(7.3)$ \\
\hline 16. & Have payroll deduction for savings & 490 & $(67.9)$ & 222 & $(31.2)$ \\
\hline 17. & Consistently keep in savings account & 469 & $(66.1)$ & 240 & $(33.9)$ \\
\hline 18. & Own insurance/ takaful hayat & 367 & $(51.5)$ & 345 & $(48.5)$ \\
\hline 19. & Own insurance/ takaful kesihatan & 362 & $(50.8)$ & 351 & $(49.2)$ \\
\hline 20. & Saving for old age & 576 & $(80.9)$ & 136 & $(19.1)$ \\
\hline 21. & Have a will & 205 & $(28.8)$ & 506 & $(71.2)$ \\
\hline 22. & Keep record for debt payment & 505 & $(69.9)$ & 208 & $(29.2)$ \\
\hline 23. & Have children education savings & 412 & $(57.9)$ & 300 & $(42.1)$ \\
\hline 24. & Saving for emergency & 609 & $(85.4)$ & 104 & $(14.6)$ \\
\hline 25. & Have a debt list & 458 & $(64.1)$ & 256 & $(35.9)$ \\
\hline 26. & Plan before taking any loan & 600 & $(84.0)$ & 114 & $(16.0)$ \\
\hline 27. & Saving for long term goal & 613 & $(85.7)$ & 102 & $(14.3)$ \\
\hline 28. & Will have a financial planning needs for short-term goals & 550 & $(77.0)$ & 164 & $(23.0)$ \\
\hline 29. & Own a fixed deposit account & 395 & $(55.3)$ & 319 & $(44.7)$ \\
\hline 30. & Own a saving account & 642 & $(89.5)$ & 75 & $(10.5)$ \\
\hline 31. & Own a current account & 419 & $(58.8)$ & 294 & $(41.2)$ \\
\hline 32. & Nominated beneficiaries & 377 & $(52.8)$ & 337 & $(47.2)$ \\
\hline 33. & $\begin{array}{l}\text { Save and manage their money through ibadah, for } \\
\text { example zakat, haji, sedekah and waqaf }\end{array}$ & 511 & $(71.5)$ & 204 & $(28.5)$ \\
\hline
\end{tabular}


According to Okpara (2011), most women do not have financial management skills such as bookkeeping, inventory management, personnel management, and basic marketing hence most business owners end up losing track of their daily transactions and cannot account for their expenses and profits at the end of the month [14]. But, according to the results of the current study majority of the Malaysian women's financial management skills were higher, for example, keep an expenses record is $86.1 \%$. The contradictory results are due to higher educational background of Malaysian women than African women.

\section{Savings Behavior}

Several saving options were given to the respondents to choose, and most of the respondents $(74.3 \%)$ chose to save their money in a bank account, followed by $65 \%$ respondents who did their savings in Tabung Haji, 33.2\% considered saving in the Employee Provident Fund (EPF), 31.9\% in a Coorperative set up, $21.8 \%$ in a fixed deposit, $14.9 \%$ in the Skim Simpanan Pendidikan Nasional (SSPN), and 12.2\% in the Sijil Simpanan Premium (SSP). Most of the respondents $(96.8 \%$ ) had their own savings account, and $52.9 \%$ of respondents did their savings once in every month. About $18.4 \%$ respondents stated that they only did their savings when they had extra money. Around $13.1 \%$ respondents did their savings every two or three months, and $11 \%$ of the respondents saved their money occasionally. Each respondent was asked to estimate their total saving amount, and $72.4 \%$ respondents mentioned that their saving only amounted to a sum of below RM3,000 and only $20 \%$ of the respondents were able to save above RM5,000. Meanwhile, the respondents were also given 32 options to choose from to explain six reasons they had for saving. The highest rate that chosen was for retirement whereby most of the respondents cited it as the first reason for saving. The second highest reason for saving was for emergencies, with $16.1 \%$. The third reason was to "save for the children" which made up of $16.9 \%$ of the respondents. Followed by fourth reason where $11 \%$ of the respondents identified savings for their future used. The fifth reason for saving was to help to increase their living standards which made up $9.8 \%$ of the respondents. The final reason chosen by the respondents made up $10.1 \%$ was for the purpose of enjoying the life.

The data also showed that $61.1 \%$ of the respondents' major financial goal was to achieve long term financial funds. About $18.1 \%$ respondents showed that their financial goal was for emergency use while $11.8 \%$ respondents' financial goal was having a retirement income. But, a mere $7.9 \%$ was for their current income. Surprisingly, only $36.3 \%$ respondents planned how much they needed to save for their future use. This illustrates the fact that most people only save blindly but do not have a proper planning strategy for their savings. However, when respondents were asked about how long they can live if they lost their key source of income without borrowing from others, only $22.9 \%$ respondents indicated that they could survive at least one month, but not more than three months. Only $19.3 \%$ respondents indicated that they can live for at least three months but not exceeding six months.

Table 4. Savings Behavior Data

\begin{tabular}{|c|c|c|}
\hline Items & $\mathbf{n}$ & $\%$ \\
\hline \multicolumn{3}{|l|}{ Savings account } \\
\hline Yes & 695 & 96.8 \\
\hline No & 23 & 3.2 \\
\hline \multicolumn{3}{|l|}{ Frequency to make savings } \\
\hline Once a month & 380 & 52.9 \\
\hline 2 - 3 months & 94 & 13.1 \\
\hline 3 - 4 months & 28 & 3.9 \\
\hline Occasionally & 79 & 11.0 \\
\hline 6 months & 6 & 0.8 \\
\hline When have extra money & 132 & 18.4 \\
\hline \multicolumn{3}{|l|}{ Estimated total savings (RM) } \\
\hline Below 3,000 & 523 & 72.4 \\
\hline $3,001-5,000$ & 36 & 5.0 \\
\hline 5,001 above & 145 & 20.0 \\
\hline \multicolumn{3}{|l|}{ Mean $=137.84$} \\
\hline \multicolumn{3}{|l|}{ Savings types } \\
\hline Tabung Haji & 468 & 65.0 \\
\hline Sijil Simpanan Premium (SSP) & 88 & 12.2 \\
\hline Employee Provident Fund (EPF) & 239 & 33.2 \\
\hline
\end{tabular}


Cooperative

Bank savings

Fixed deposit

Skim Simpanan Pendidikan Nasional (SSPN)

Others

Main reason to save money

First (Retirement)

Second (Emergency)

Third (Keep for children)

Forth (Future used)

Fifth (Increase standard living)

Sixth (Enjoyed life)

Long term financial funds

Retirement income

Current income

Emergency used

Do you ever plan for how much to save for future use
31.9

74.3

21.8

14.9

15.1

34.4

16.1

16.9

11.0

9.8

10.1

61.1

11.8

7.9

18.1

$131+18.1$

$\begin{array}{lll}\text { Yes } & 260 & 36.3\end{array}$

No

457

Some of the results are consistent with previous research conducted by Sabri and Juen (2014), for example, the percentage of Malaysian working women that had a personal savings account in the bank $(96.3 \%)$ is in line with the findings of the current study [20]. All the other factors that are related to the savings behaviour of public sector women are not examined previously, and therefore, no previous research were found that are compatible with them.

\section{Investment Behavior}

Only the respondents who did investments were asked to fill up this section, and $44.8 \%$ respondents stated that they have already planned their investments. In relation to the frequency of the respondents' investments, $38.1 \%$ of the respondents invested once a month, while $32.1 \%$ of the respondents only did their investment when they had extra money. Meanwhile, $14.2 \%$ respondents had invested occasionally. About $44.6 \%$ respondents claimed that their investment objective was used the benefits after their retirement. Only $27.6 \%$ of the respondents aimed for capital growth returns, and $12.6 \%$ targeted for capital security. More than half $(59.4 \%)$ of the respondents invested in Unit trust. This is followed by $15.8 \%$ invested in property, and $15.2 \%$ invested in investment links. But, the investment ventures need to be based on expert advices to ensure investment security. However, only $17.9 \%$ of the respondents actually sought the advice of professionals. Only $71.2 \%$ of the respondents had at least one-year investment experience, and $10.4 \%$ of the respondents had less than 3 months' experience. Further, $30.1 \%$ respondents felt that investments are not risky. In contrast, only $1.5 \%$ respondents felt that investments are very risky for them. About $72 \%$ respondents plan to invest at least once every three months, and most of the respondents asked advice from their partners when it came to making a decision on investment options. Moreover, results show that, $38.8 \%$ of the respondents got advice from their family on investment options, and 38\% was based on their friend's advices. Others (32.1\%) received investment information from the internet. Other than that, $30.9 \%$ of them took their investment information from television or radio, and $30.3 \%$ from newspaper, magazine or other writing materials. Only $28.6 \%$ respondents obtained suggestions from a professional financial planner or trader on their investment options. But, $11.7 \%$ of the respondents received advices from any organization or association on the viability of their investments (See Table 5). 
Table 5. Investment Behavior Data

\begin{tabular}{|c|c|c|}
\hline Items & $\mathbf{n}$ & $\%$ \\
\hline \multicolumn{3}{|l|}{ Do you ever plan for investment } \\
\hline Yes & 288 & 44.8 \\
\hline No & 355 & 55.2 \\
\hline \multicolumn{3}{|l|}{ Investment Frequency } \\
\hline Once a month & 177 & 38.1 \\
\hline $2-3$ months & 45 & 9.7 \\
\hline $3-6$ months & 12 & 2.6 \\
\hline When have extra money & 149 & 32.1 \\
\hline Occasionally & 66 & 14.2 \\
\hline When get bonus & 15 & 3.2 \\
\hline \multicolumn{3}{|l|}{ Investment objectives } \\
\hline Capital security & 58 & 12.6 \\
\hline Retirement & 205 & 44.6 \\
\hline Tax reduction & 4 & 0.9 \\
\hline Liquidity & 45 & 9.8 \\
\hline Capital growth returns & 127 & 27.6 \\
\hline Others & 21 & 4.6 \\
\hline \multicolumn{3}{|l|}{ Investment type } \\
\hline Unit Trust & 383 & 59.4 \\
\hline Property & 102 & 15.8 \\
\hline Bond & 9 & 1.4 \\
\hline Stock/ Equity & 15 & 2.3 \\
\hline FOREX & 18 & 2.8 \\
\hline Gold/ Dinar & 29 & 4.5 \\
\hline Investment Link & 98 & 15.2 \\
\hline Others & 14 & 2.2 \\
\hline \multicolumn{3}{|l|}{ Advice from professional } \\
\hline Yes & 115 & 17.9 \\
\hline No & 528 & 82.1 \\
\hline \multicolumn{3}{|l|}{ When have you started investing (months) } \\
\hline Less than 3 & 47 & 10.4 \\
\hline $3-<6$ & 30 & 6.7 \\
\hline $6-<8$ & 21 & 4.7 \\
\hline $8-12$ & 32 & 7.1 \\
\hline More than 12 & 321 & 71.2 \\
\hline \multicolumn{3}{|l|}{ Level of investment risk } \\
\hline Not risky at all & 57 & 12.4 \\
\hline Not risky & 138 & 30.1 \\
\hline Neutral & 234 & 51.1 \\
\hline Risk & 22 & 4.8 \\
\hline Very risky & 7 & 1.5 \\
\hline \multicolumn{3}{|l|}{ Frequency for investment planned } \\
\hline Plan to invest at least once every three months & 334 & 72 \\
\hline Try to invest at least once every three months & 339 & 74 \\
\hline Invest one in every three months & 352 & 77 \\
\hline \multicolumn{3}{|l|}{ Make decision source (choose more than 1 answer) } \\
\hline Information from partner & 287 & 44.4 \\
\hline Suggestion from professional financial & 185 & 28.6 \\
\hline Bank or financial institution & 259 & 40.0 \\
\hline Family advices & 251 & 38.8 \\
\hline Friends advices & 246 & 34.0 \\
\hline Written material received in workplace & 142 & 21.9 \\
\hline Newspaper, magazine or others writing material & 219 & 30.3 \\
\hline Information from television or radio & 200 & 30.9 \\
\hline
\end{tabular}


All the factors that are related to the investment behaviour of public sector women are not examined previously, and therefore, no previous research were found that are compatible with the current results.

\section{FWB}

Figure 1 shows the overall level of satisfaction of participants' current financial situation. About $22.5 \%$ of the participants were slightly unsatisfied about their current financial state, and followed by

$21.5 \%$ who are slightly happy about the current situation of their finance. Only $2.5 \%$ respondents indicated that they were very unsatisfied towards this statement, and another $2.8 \%$ respondents showed that they were very satisfied with the prevailing financial condition. Apparently, most of the respondents were satisfied with their current financial situation.

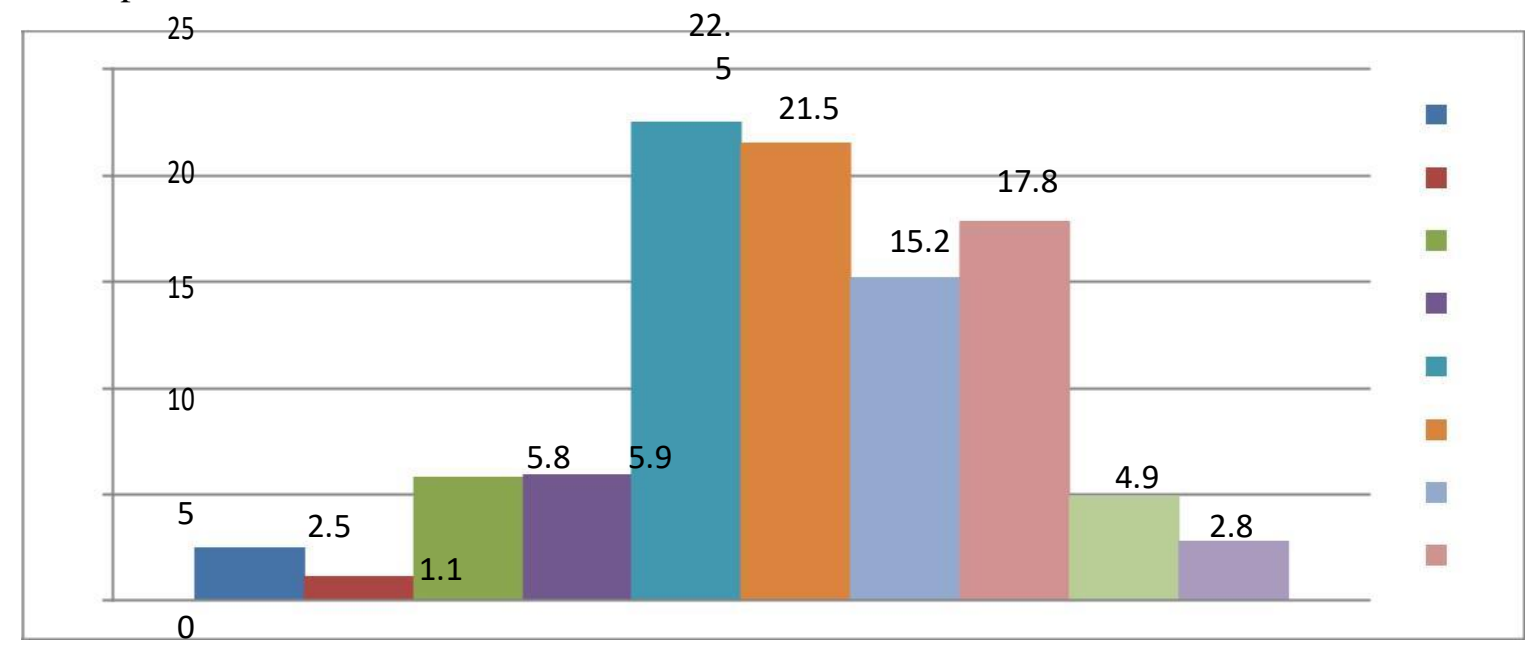

Fig. 1. Overall level of satisfaction with respondents' current financial situation

Note: Scale from 1 (very unsatisfied) to 10 (very satisfied

Most of the respondents $(22.8 \%)$ stated that they were a little bit worried about their current financial situation (Figure 2). Followed by this, $19.9 \%$ of the respondents were neutral to this statement. Meanwhile, $5.5 \%$ of the respondents were always worry about their present financial situation, and only $2.7 \%$ respondents were never worried about it. In sum, slightly more respondents were worried about their existing financial situation than those who were not (see the Figure 2).

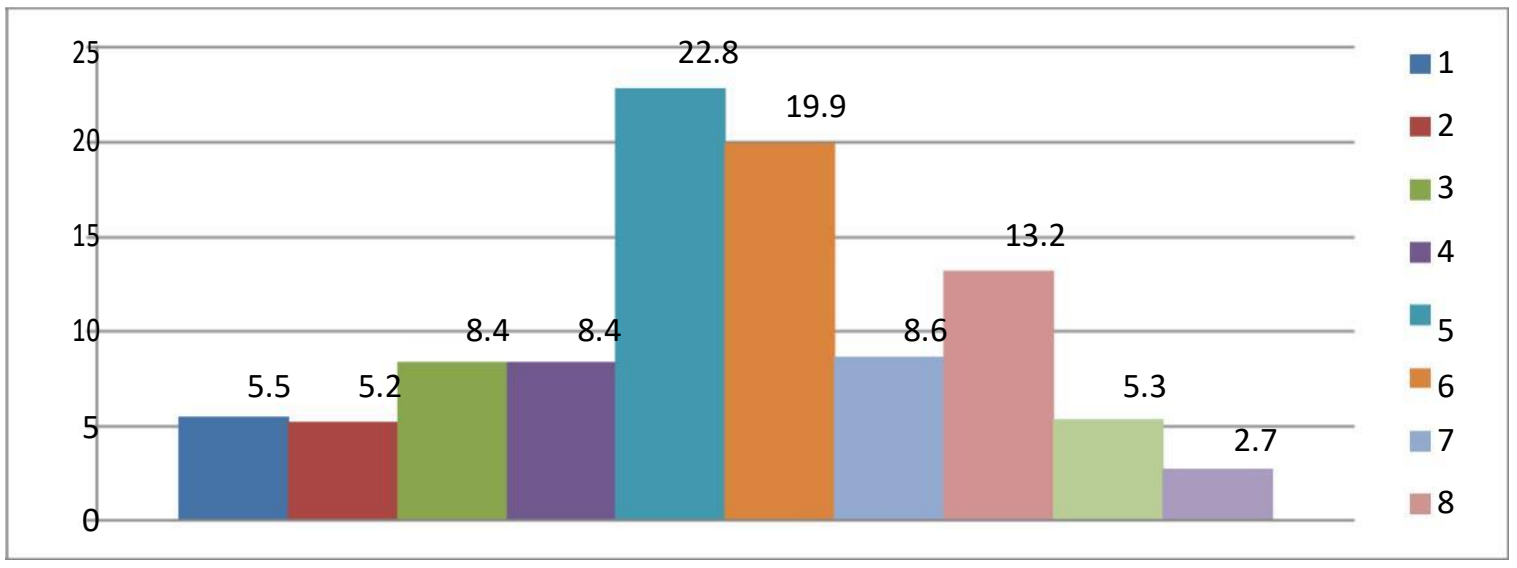

Fig. 2. Worry about your current financial situation

Note: Scale from 1 (always worry) to 10 (no worry at all)

Small percentage of respondents $(1.1 \%)$ stated that their financial situation was not good at all. Whereas $3.5 \%$ respondents showed that their financial situation was very good. Most of the respondents $(24.2 \%)$ stated that their financial situation was at a neutral position. In summary, only few respondents showed that their financial situation was not good (see the Figure 3 ). 


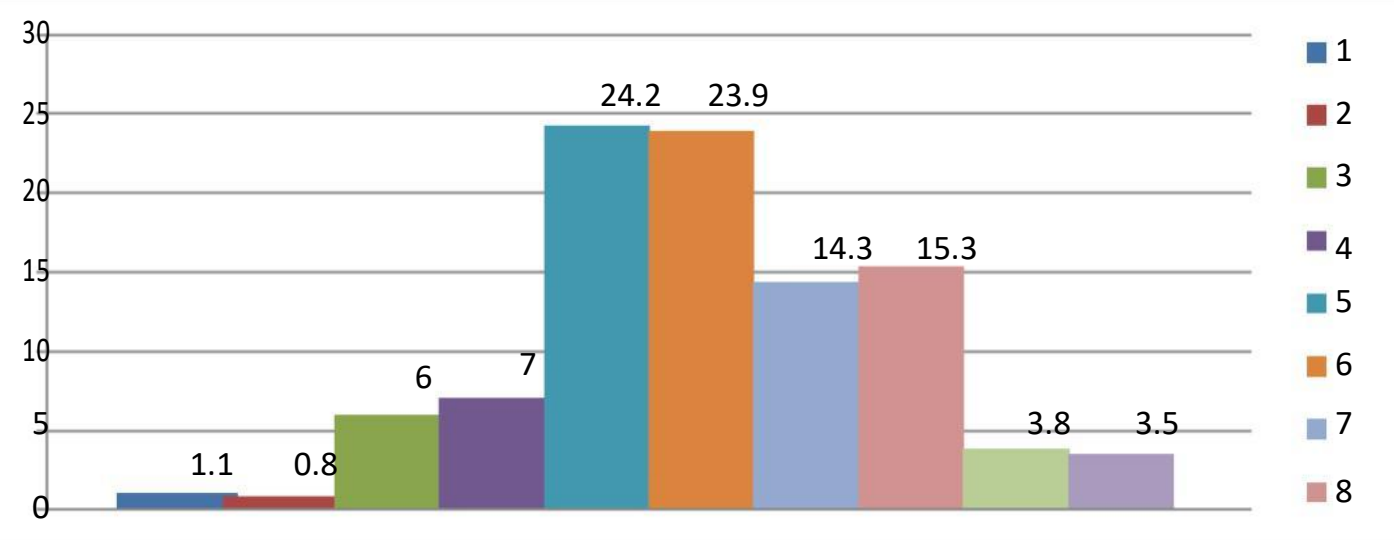

Fig. 3. How well is your financial situation

Note: Scale from 1 (not good at all) to 10 (very good)

Only $0.3 \%$ respondents admitted that an overall overview of their current financial adequacy was very low by subscribing the answer "always not enough". A slightly higher percentage $(2.2 \%)$ of the respondents claimed their current financial adequacy was more than enough. The highest score for this section is $25.3 \%$ and the respondents claimed that they considered their financial adequacy as being sometimes not enough. Hence, many respondents felt their financial adequacy were enough for them (see the Figure 4).

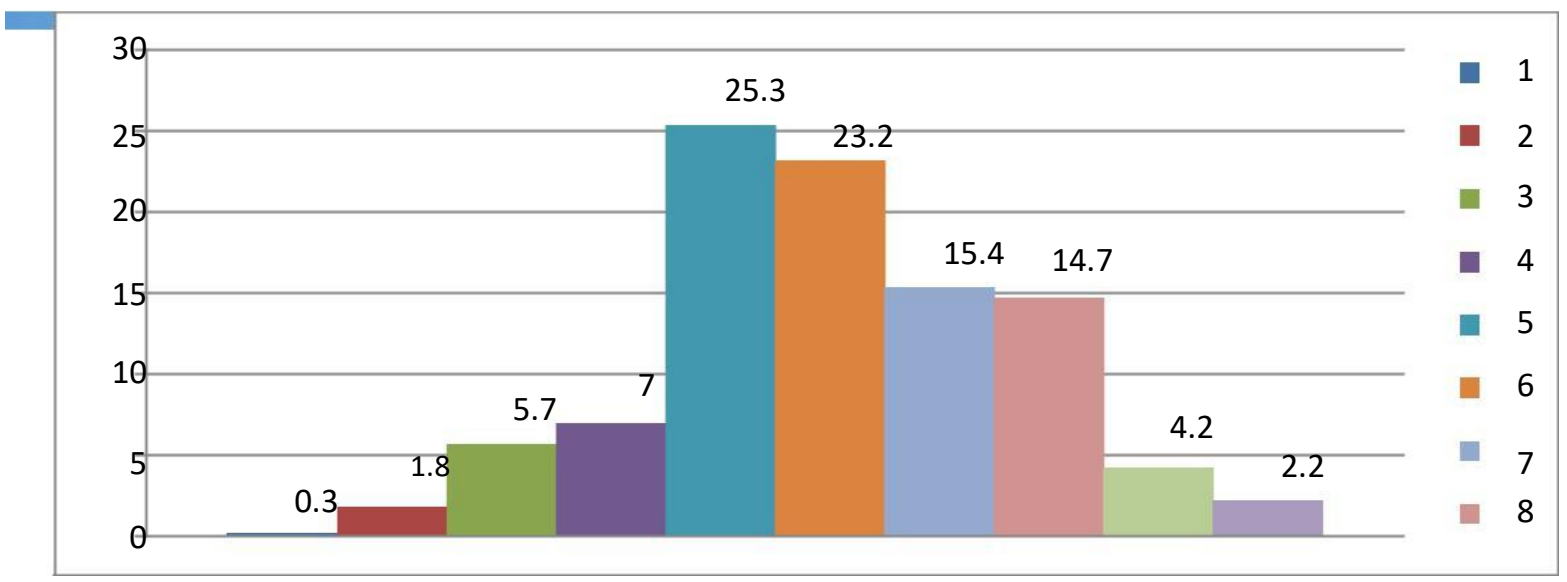

Fig. 4. An overview of your current financial adequacy

Note: Scale from 1 (always not enough) to 10 (more than enough)

In this section (see the Figure 5), only 1.4\% respondents felt very uncomfortable, and $25.6 \%$ of the participants felt slightly uncomfortable with the financial situation that they experienced. However, $2.0 \%$ respondents were expressed that they were very comfortable, and $20.4 \%$ respondents felt slightly comfortable with the prevailing financial situation with them. To sum up, most respondents were comfortable with their current financial situation. 


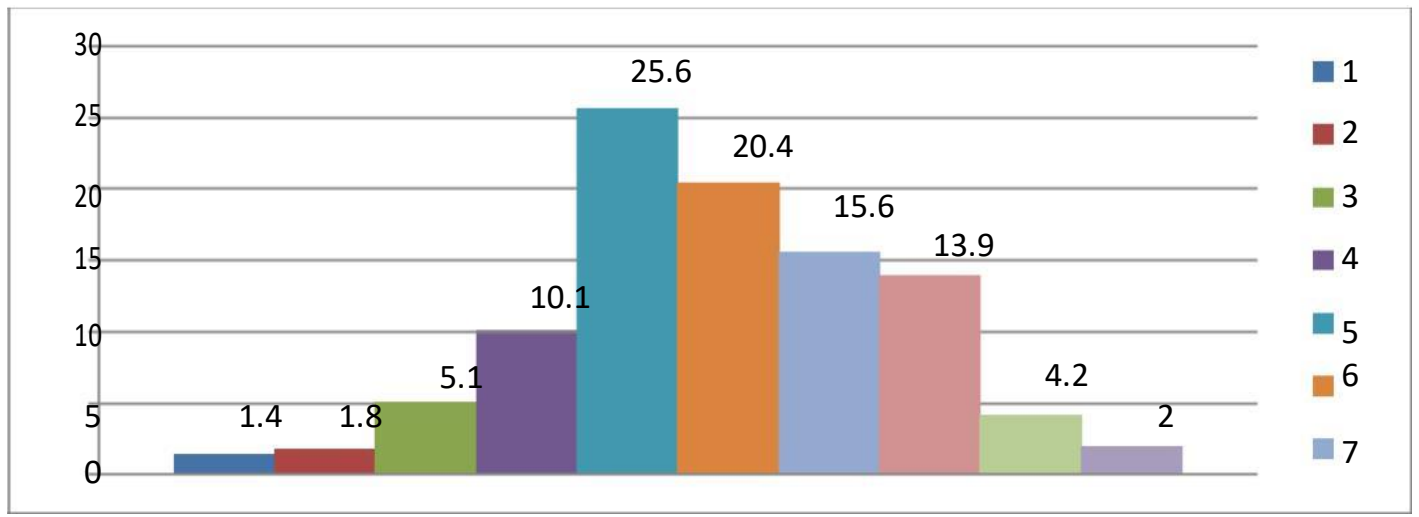

Fig. 5. Feeling of comfortable about your current financial situation

Note: Scale from 1 (very uncomfortable) to 10 (very comfortable)

According to the Figure 6,1.3\% respondents had no confidence at all in having adequate money to spend a comfortable retirement life, and $21.2 \%$ respondents had slightly less confidence that their retirement life would comfortable. But, $3.1 \%$ respondents were very confident of having sufficient money for their future retirement life. While, $20.7 \%$ was slightly confident with the statement. Therefore, in sum, most of the respondents had confidence that they would have an adequate amount of money to live a comfortable retirement life in the future.

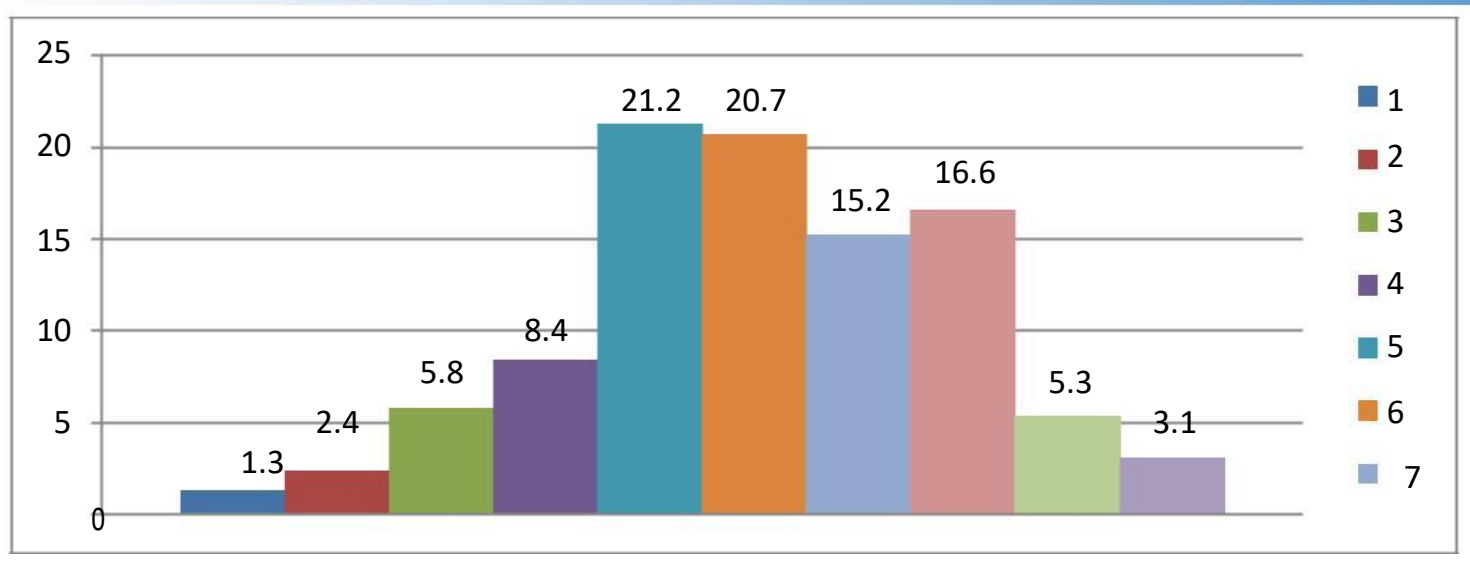

Fig. 6. Confidence in having enough money to cover living a comfortable retirement life Note: Scale from 1 (no confidence at all) to 10 (very confidence)

Apparently, only $5.2 \%$ respondents never ran out of money before the next payment. Meanwhile, $21.7 \%$ had experienced this situation several times. However, $2.4 \%$ of the respondents always faced to this situation. In short, not many respondents have faced situations where they always ran out of money before their next payment (see the Figure 7). 


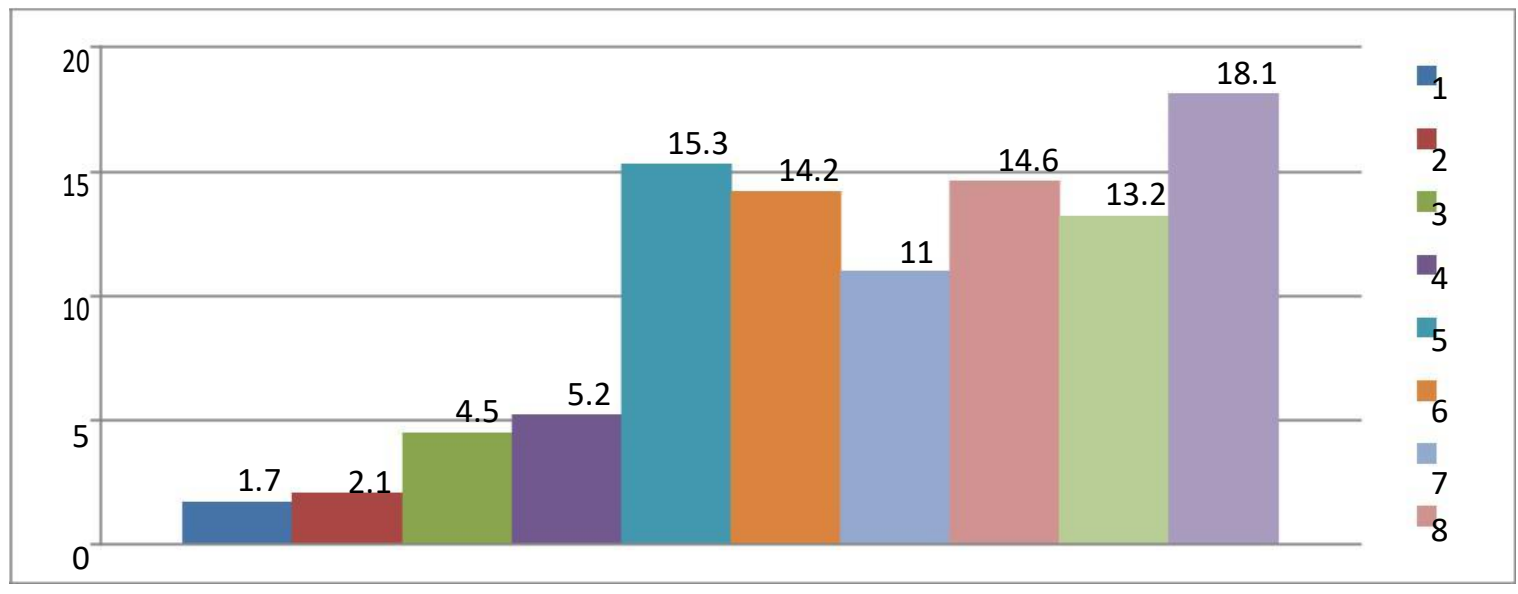

Fig. 7. Always out of money before the next payment

Note: Scale from 1 (frequently) to 10 (never)

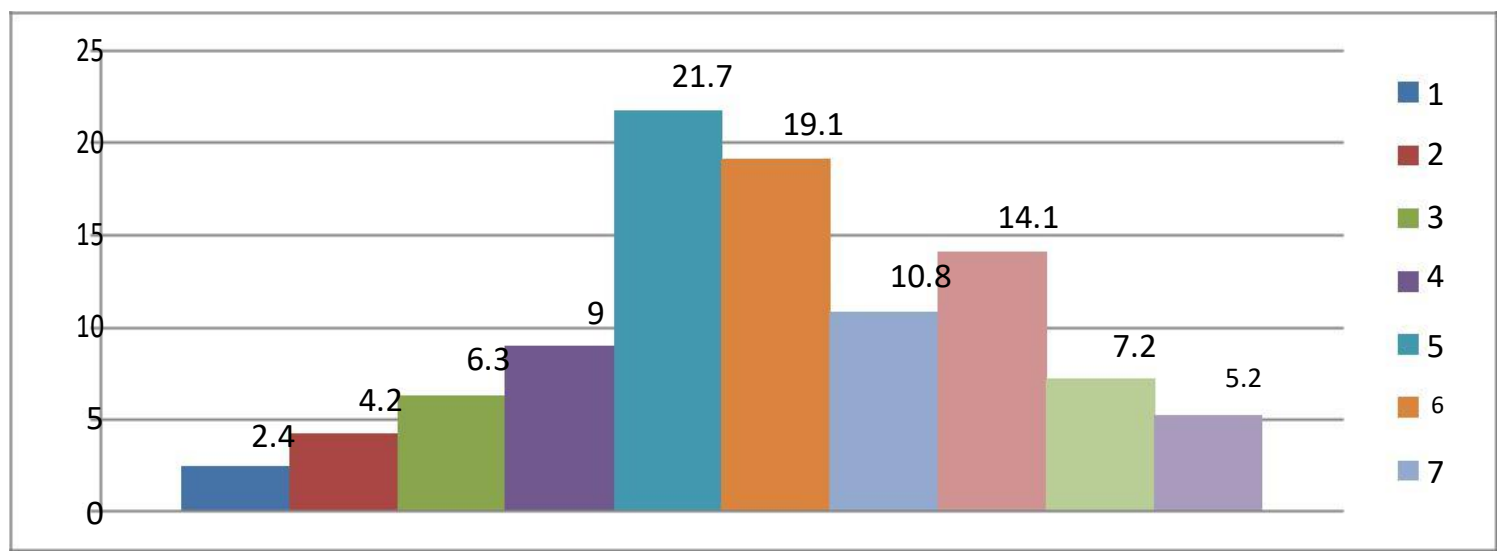

Fig. 8. Always have problems paying bills

Note: Scale from 1 (frequently) to 10 (never)

Based on the Figure 8, 18.1\% respondents never have any problems in paying their bills. However, $15.3 \%$ of the respondents admitted to having tried to fulfill their obligations of paying bills on time a few times. Unfortunately, $1.7 \%$ respondents faced this situation frequently. Overall, most respondents do not face any difficulty in paying bills.

Figure 9 showed that $9.2 \%$ respondents were very confident that they had the ability to manage their own finances. While, $16.6 \%$ were slightly confident with their personal finance controlling power. Only $1.0 \%$ of the respondents had no confidence at all with their power, and $18.5 \%$ respondents had less confidence with controlling their personal finances. Apparently, most respondents had the confidence to control their personal finances.

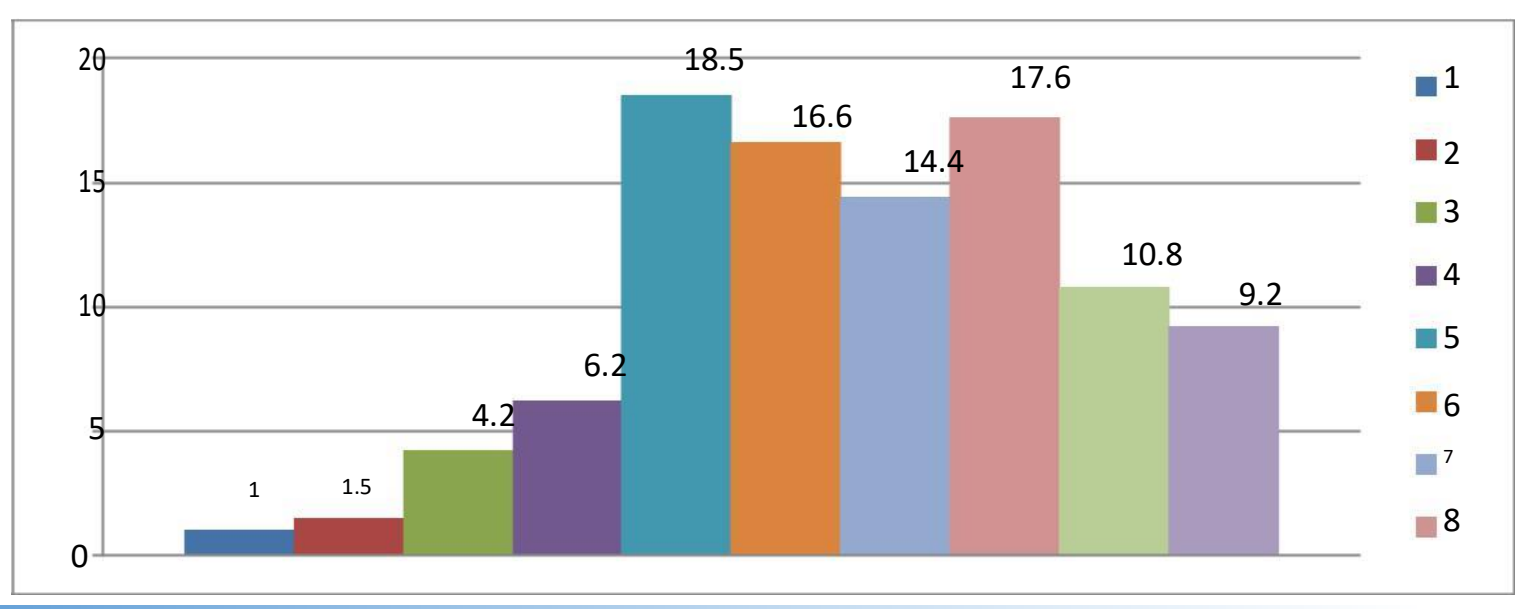


Fig. 9. Confidence that you have the power to control your personal finances Note: Scale from 1 (no confidence at all) to 10 (very confidence)

According to the results of the Figure 10, 8.4\% participants were very confident that they can manage their finances on their own. But, $17.4 \%$ respondents had a slight confidence that they can handle their finances on their own. Only $0.8 \%$ respondents had no confidence at all that they could control their finances. To summarize, many respondents were confident that they would be able to control their finances on their own.

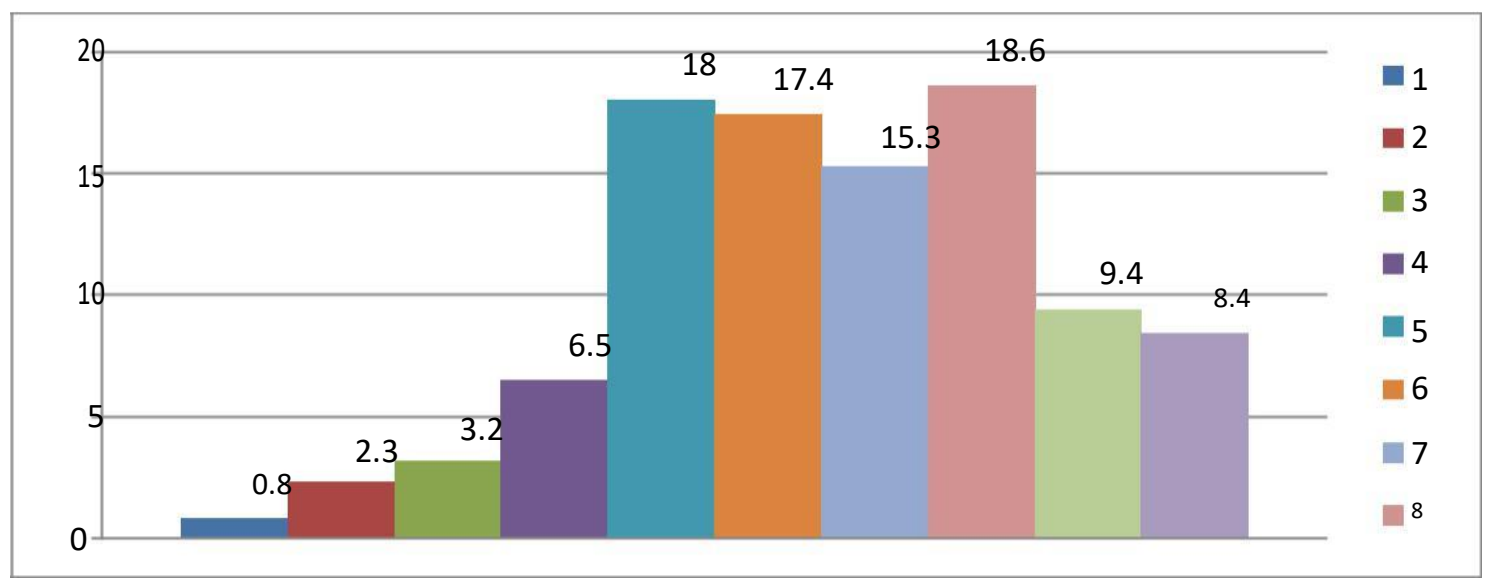

Fig. 10. Confidence that you can control your finances

Note: Scale from 1 (no confidence at all) to 10 (very confidence)

About $9.3 \%$ of the respondents stated that they felt it was easy to get RM1, 000 for an emergency. This showed that they were well prepared to face an emergency. Whereas, $4.5 \%$ of the respondents felt it was not easy at all to obtain RM1, 000 in case of any emergencies. But, $17.6 \%$ of the respondents indicated that they could have RM1, 000 with some time. Therefore, many of the respondents are able to handle their financial problems during an emergency (see Figure 11).

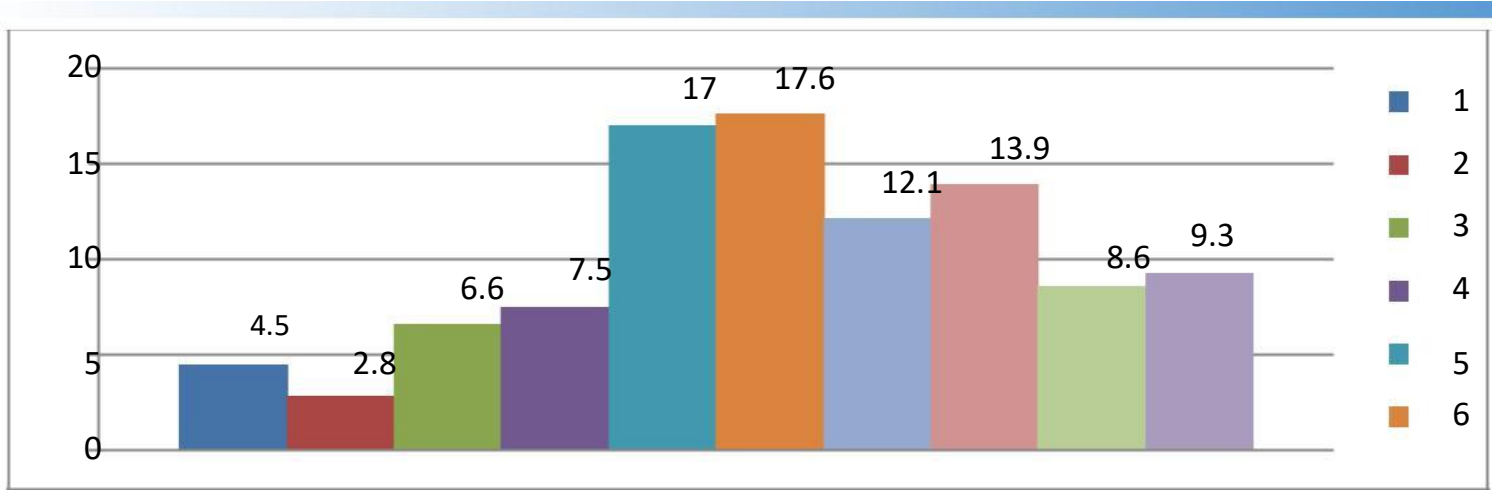

Fig. 11. How easy can you get RM1,000 in case of an emergency

Note: Scale from 1 (not easy at all) to 10 (very easy)

Only $3.5 \%$ respondents were never worry with their overall FWB or status. This is the opposite of the $4.8 \%$ respondents who always worried over with their overall financial situation. This showed that they did not keep an eye for their financial problems, while $19.0 \%$ respondents were slightly worried with their overall financial status. Thus, quite a number of respondents do not worry about their overall financial (see Figure 12). 


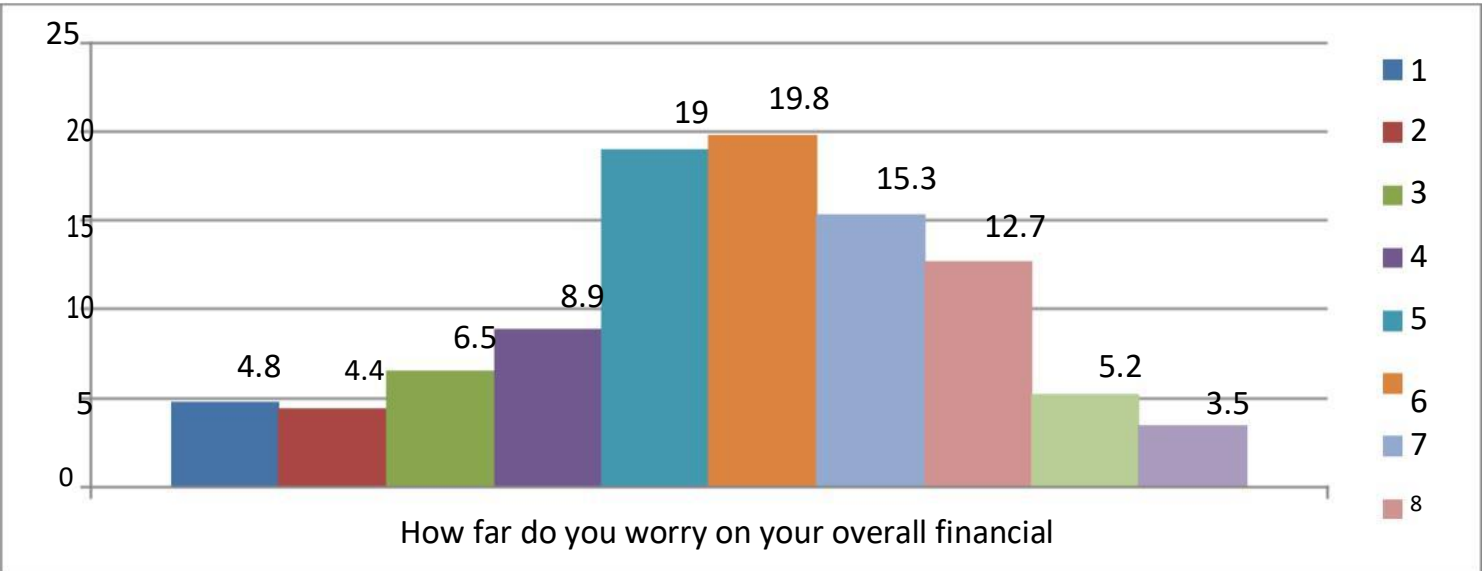

Fig. 12. How far do you worry about your overall financial status

Note: Scale from 1 (always worry) to 10 (no worry at all)

In general, the women working in the public sector in Malaysia show a moderate level of financial well-being, and it is in line with the previous findings of Mokhtar et al. (2015) in the study of "Financial well-being among public employees in Malaysia"

\section{CONCLUSION}

This paper explains descriptively the status of the variables; financial management, savings behaviour, investment behavior, and FWB of working women in the government departments in Malaysia. According to the financial status, $39.2 \%$ participants told that their debts were less than their assets, trailed by $33.7 \%$ said that both of their debts and assets were equal, and $23.9 \%$ were stated that they have a debt. Based on the income adequacy results, $44.3 \%$ was felt that their income was only sufficient to fulfill their basic needs, and $29 \%$ specified that the income was enough for them to cover most of their expenses. Unfortunately, $16.1 \%$ the respondents were stated that the income that they received from the job was not adequate to fulfill all their needs that they wished. Furthermore, majority of the respondents $(81.8 \%)$ considered their pensions as their retirement income source in the future, and $56.4 \%$ kept savings as their source of income during the retirement life.

Based on the assessed financial management practices more than $80 \%$ of the respondents were followed the good practices to manage their finance efficiently for example, keeping updated records of the expenses, planning the expenses, doing investments monthly, keeping the loan payment on schedule, settling all the bills on time, and maintaining a savings account. Among several savings options most of them (74.3\%) chose to save their money in a bank account, and less numbers use other type of savings such as, Tabung Haji, EPF, fixed deposit, the Skim Simpanan Pendidikan Nasional (SSPN), and the Sijil Simpanan Premium (SSP), and more than half did their savings once in every month. But, $72.4 \%$ of the respondents saving sum was below RM3,000. Further, it was revealed that the $44.8 \%$ respondents have already planned their investments, and majority of them were invested once a month. The major purpose of their investments was used the benefits after their retirement.

Finally, from the results of the study of Malaysian working women's FWB the majority of them were; satisfied with their present financial situation, had enough financial adequacy, selfconfident with retirement security, had no difficulty in paying bills, and had to control their finances on their own. Therefore, financially empowered women are capable to enjoy well-being and furthermore, support in increasing productivity, reducing poverty, enhancing efficiency, and economic growth. Moreover, due to the multiple roles that women play nowadays on a daily basis, as consumers, household managers, employees and employers in the both private and public sectors, or as business owners, sound knowledge on financial management, and savings and investment behavior are extremely important so as to accomplish higher FWB levels. 


\section{RESEARCH IMPLICATIONS}

The working women, private and government regulatory bodies, and the policy makers can implement the results of this research for the empowerment of the working women in Malaysia, because economically empowered women are performed well at work place by expanding productivity, enhancing opportunities, and possibilities. Expanded interest and contribution of women in work force is important to increase the efficiency of work and help to achieve higher well-being of both those women and their families as a whole. This investigation likewise highlighted the areas, such as, insufficient positive financial attitudes, financial management practices, and less tendency towards the investments and savings, that are mandatory to develop for making working women financially empowered to achieve higher FWB levels. Consequently, authors recommend financial literacy programs to develop positive financial attitudes towards the proper financial management practices, and saving and investment behaviors in order to reach higher FWB levels of the working women in Malaysia, because the direct influence of financial education programs in order to uplift positive financial practices to improve the FWB of employees was previously stated by Sabri, Wijekoon and Rahim in 2019.

\section{REFERENCES}

Malaysian Financial Planning Council. "Report of National Findings 2018: Financial capability \& utilization of financial advisory services in Malaysia," Kuala Lumpur, Malaysia, 2018.

Lusardi, and P. Tufano, "Debt literacy, financial experiences and over indebtedness," Working Paper

Dartmouth College. Accessed on 10/04/2020 from http:// www.dartmouth.edu/ alusardi/Papers/ Lusardi_Tufano.pdf, 2009.

National Center for Education Statistics, 2016.

U.S. Census Bureau, "Historical income tables,” 2015.

AKPK Financial Behavior Survey, "Financial behavior and state of FWB of Malaysian working adults," Kuala Lumpur, Malaysia, 2018.

S. Mboko, and A. E. Smith-Hunter, "Women entrepreneurs in Zimbabwe: A case study," J. Glob. Bus. Iss., vol. 3(1), pp. 157-170, 2009.

R. Sellappan, M. S. Jamuna, and M. T. Kavitha, "Investment attitude of women towards different sources of securities-A factor analysis approach,” Glo. J. Mgt. Bus. Res., vol. 13(3), pp. 27-30, 2013.

Management Study Guide. "Financial Management - Meaning, objectives and functions," Accessed on 10/04/2020 from https://www.managementstudyguide.com/financial-management.htm, 2020.

M. A. Hilgert, J. M. Hogarth, and S. G. Beverly, "Household financial management: The connection between knowledge and behavior," Fed. Res. Bul., vol. 87, pp. 309-322, 2003.

The GSMA. "Unlocking the potential: Women and mobile financial services in emerging markets.

Accessed on 10/04/2020 from https://www.gsma.com/mobilefordevelopment/wp-content/ uploads/ 2013/02/GSMA-m Women-Visa_Unlocking-the-Potential_Feb-2013.pdf, 2013.

T. Nyamwanza, D. Mapetere, S. Mavhiki, and C. Dzingirai, "Financial management: Case study of Gweru women entrepreneurs,” Int. J. Bus. Soc. Sci., vol. 3(18), 2012.

J. O. Okpara, "Strategic choices, export orientation and export performance of SMEs in Nigeria," Mgt. Dec., vol. 4(8), pp. 1281-1299, 2009. doi.org/10.1108/00251740910984541. 
M. Karami, L. Moradi, M. Y. Mazhari, F. Yarkarami, and S. Khan, "Financial management and women entrepreneurship in Malaysia,” Int. j. manag. commerce innov., vol. 2(1), pp. 37-43, 2014.

A. Lusardi, and L. Mitchell, "Financial literacy and retirement preparedness: Evidence and implications for financial education," Buss. Econ., vol. 42(1), pp. 35-44, 2007.

J. Lupton, and J. P. Smith, "Marriage, assets, and savings". In S. Grossbard-Shechtman (Ed.), Marriage and the Economy: Theory and Evidence from Industrialized Societies (pp. 129-152). Cambridge, England: Cambridge University Press, 2003.

P. J. Fisher, "Gender differences in personal saving behaviors,” J. Financial Couns. Plan., vol. 21(1), 2010.

Financial Education Network, "Malaysia National Strategy for financial literacy 2019-2023," Kuala Lumpur, Malaysia, 2019.

M. F. Sabri, and T. T. Juen, "The influence of financial literacy, saving behavior, and financial management on retirement confidence among women working in the Malaysian public sector," Asian Soc. Sci., vol. 10(14), pp. 40-51, 2014. doi:10.5539/ass.v10n14p40.

L. X. Zhong, and J. J. Xiao, "Determinants of family bond and stock holdings," J. Financial Couns. Plan., vol. 6, pp. 107-114, 1995.

K. A. Hassett, "Investment, Concise Encyclopedia of Economics," 2nd ed., 2008.

E. K. Chowdhury, "Investment behavior: A study on working women in Chittagong," Premier Critical Perspective, vol. 2(1), pp. 77-93, 2016.

N. Delafrooz, and L. Paim, "Personal saving behavior among Malaysian employees: Socio demographic comparison," Education, vol. 3, pp. 361-363, 2011.

T. M. Hemalatha, and S. Pavithra, "A study on savings and investment pattern of salaried women in Coimbatore District,” Int. j. res. anal. rev., vol. 5(3), pp. 143-148, 2018.

H. Janor, R. Yakob, N. A. Hashim, Z. Zanariah, and C. A. C. Wel, "Financial literacy and investment decisions in Malaysia and United Kingdom: A comparative analysis," Malaysian Journal of Society \& Space, vol. 12(2), pp. 106-118, 2017.

L. Schmidt and P. Sevak, "Gender, marriage, and asset accumulation in The United States," Fem. Econ., vol. 12(1 - 2), pp. 139 - 166, 2006. doi.org/10.1080/13545700500508445.

N. Asandimitra, T. S. Aji, and A. Kautsar, "Financial behavior of working women in investment decision-making," Info. Mgt. Bus. Rev., vol. 11(2 (I)), pp. 10-20, 2019. doi.org/10.22610/imbr.v11i2(I).2878.

J. Watson, and M. McNaughton, "Gender differences in risk aversion and expected retirement benefits," Financial Anal. J., vol. 63(4), pp. 52-62, 2007. doi.org/10.2469/faj.v63.n4.4749.

A. Bernasek, and S. Shwiff, "Gender, risk, and retirement," J. Econ. Issues, vol. 35(2), pp. 345-356, 2001. doi.org/10.1080/00213624.2001.11506368.

R. Jain, "An analysis of income and investment pattern of working women in the city of Ahmedabad," IRACST-Int. J. Res. Mgt. Tech., vol. 4(6), pp. 139-146, 2014.

B. M. S. Van-Praag, P. Frijters, and A. Ferrer-i-Carbonel, "The anatomy of subjective well-being," J. Econ. Behav. Organ., vol. 51, pp. 29-49, 2003. doi.org/10.1016/S0167-2681(02)00140-3. 
CFPB, "FWB: The goal of financial education," Consumer Financial Protection Bureau, vol. 3, pp. 2 48, 2015.

S. Joo, "Personal financial wellness," Unpublished doctoral dissertation,Virginia Polytechnic Institute and State University. Blacksburg. http://link.springer.com/ chapter/ 10.1007\%2F978-0-38775734-6_2\#page-1, 2008.

J. Kim, E. T. Garman, and B. Sorhaindo, "Relationships among credit counselling clients' FWB, financial behaviors, financial stressor events, and health," Fin. Counsel. Plan. Edu., vol. 14(2), pp. 75-87, 2003.

The World Bank, "Annual Report 2013," Accessed on 20/04/2020 from http://siteresources.worldbank.org/EXTANNREP2013/Resources/9304887-1377201 212 378/ 9305896-1377544753431/1_AnnualReport2013_EN.pdf, 2013.

M. F. Sabri, and L. Falahati, "Predictors of FWB among Malaysian employee: Examining the mediate effect of financial stress," J.Emerg. Econ. Islam. Res., vol. 1(3), pp. 1-16, 2003.

N. Mokhtar, A. R. Husniyah, M. F. Sabri, and M. A. Talib, "FWB among public employees in Malaysia: A preliminary study," Asian Soc. Sci., vol. 11(18), pp. 49, 2015. doi:10.5539/ass.v11n18p49.

Close Brothers' Financial Wellbeing Index, "Why is women's financial wellbeing so much poorer than men's?" Accessed on 10/04/2020 from file://C:/Users/User/ Downloads/Close\%20Brothers\%20-\%20Why\%20is\%20womens 20financial\%20wellbeing\% 20so\% 20 much\%20poorer\%20than\%20mens_0919.pdf, 2019.

M. T. Khan, and A. Akhter, "Impact of financial knowledge of women on the household FWB," J. Manage., vol. 5(3), pp. 80-88, 2018.

A. Haque, and M. Zulfiqar, "Women's economic empowerment through financial literacy, financial attitude and financial wellbeing,” Int. J. Bus. Soc. Sci., vol. 7(3), pp. 78-88, 2016.

A. Banff, C. Draimin, and L. Dyer, "FWB and women's retirement satisfaction," John Molson School of Business, Concordia University, Banff, Alberta, Canada, 2006.

S. M. Danes, and T. K. Hira, "Money management knowledge of college students," J. Stud. Fin. Aid., vol. 17(1), pp. 1, 1987.

M. Gutter, and Z. Copur, "Financial behaviors and FWB of college students: Evidence from a national survey," J. Fam. Econ. Iss., vol. 32(4), pp. 699-714, 2011. doi: 10.1007/s10834-011-9255-2.

J. M. Hogarth, and C. E. Anguelov, "Are families who use e-banking better financial manager?" Financial Couns. Plan., vol. 15(2), pp. 61-77, 2004.

S. A. Haron, D. L. Sharpe, M. Abdel-Ghany, and J. Masud, "Moving up the savings hierarchy: Examining savings motives of older Malay Muslim,” J. Fam. Econ. Iss., vol. 34(3), pp. 314-328, 2012. doi: $10.1007 / \mathrm{s} 10834-012-9333-0$.

B. O'Neill, A. Prawitz, B. Sorhaindo, J. Kim, and E. T. Garman, "Changes in health, negative financial events, and financial distress/FWB for debt management program clients," J. Financial Couns. Plan., vol. 17(2), 2006.

J. Kim, J. Kwon, and E. A. Anderson, "Factors related to retirement confidence: Retirement preparation and workplace financial education,” Financial Couns. Plan., vol. 12(2), pp. 77-89, 2005.

M. F. Sabri, R. Wijekoon, and H. A. Rahim, "The influence of money attitude, financial practices, self-efficacy and emotion coping on employees' FWB," Manag. Sci. Lett., vol. 10(2020), pp. 889-900, 2019. doi: 10.5267/j.msl.2019.10.007. 